\title{
Iron-Copper-Zinc Isotopic Compositions of Andesites from the Kueishantao Hydrothermal Field off Northeastern Taiwan
}

\author{
Zhigang Zeng ${ }^{1,2,3, *}$, Xiaohui Li ${ }^{1,3}{ }^{\mathbb{D}}$, Shuai Chen ${ }^{1,4}$, Yuxiang Zhang ${ }^{1}$, Zuxing Chen ${ }^{1}$ \\ and Chen-Tung Arthur Chen ${ }^{5}$ (i)
}

Citation: Zeng, Z.; Li, X.; Chen, S.; Zhang, Y.; Chen, Z.; Chen, C.-T.A. Iron-Copper-Zinc Isotopic Compositions of Andesites from the Kueishantao Hydrothermal Field off Northeastern Taiwan. Sustainability 2022, 14, 359. https://doi.org/ $10.3390 /$ su14010359

Academic Editor: Olivier Pourret

Received: 7 November 2021

Accepted: 27 December 2021

Published: 29 December 2021

Publisher's Note: MDPI stays neutral with regard to jurisdictional claims in published maps and institutional affiliations.

Copyright: (C) 2021 by the authors. Licensee MDPI, Basel, Switzerland. This article is an open access article distributed under the terms and conditions of the Creative Commons Attribution (CC BY) license (https:// creativecommons.org/licenses/by/ $4.0 /)$.
1 Seafloor Hydrothermal Activity Laboratory, CAS Key Laboratory of Marine Geology and Environment, Institute of Oceanology, Chinese Academy of Sciences, Qingdao 266071, China; xiaohuili0526@foxmail.com (X.L.); chenshuai@qdio.ac.cn (S.C.); yxzhang@qdio.ac.cn (Y.Z.); chenzuxing@qdio.ac.cn (Z.C.)

2 Laboratory for Marine Mineral Resources, Qingdao National Laboratory for Marine Science and Technology, Qingdao 266071, China

3 University of Chinese Academy of Sciences, Beijing 100049, China

4 Center for Ocean Mega-Science, Chinese Academy of Sciences, 7 Nanhai Road, Qingdao 266071, China

5 Department of Oceanography, National Sun Yat-Sen University, Kaohsiung 80424, Taiwan, China; ctchen@mail.nsysu.edu.tw

* Correspondence: zgzeng@ms.qdio.ac.cn

\begin{abstract}
The studies of iron $(\mathrm{Fe})$, copper $(\mathrm{Cu})$, and zinc $(\mathrm{Zn})$ isotopic compositions in seafloor andesites are helpful in understanding the metal stable isotope fractionation during magma evolution. Here, the $\mathrm{Fe}, \mathrm{Cu}$, and $\mathrm{Zn}$ isotopic compositions of andesites from the Kueishantao hydrothermal field (KHF) off northeastern Taiwan, west Pacific, have been studied. The majority of $\delta^{56} \mathrm{Fe}$ values (+0.02\% to $+0.11 \%$ ) in the KHF andesites are consistent with those of MORBs (mid-ocean ridge basalts). This suggests that the Fe in the KHF andesites is mainly from a MORB-type mantle. The Fe-Cu-Zn isotopic compositions ( $\delta^{56} \mathrm{Fe}+0.22 \%$, $\delta^{65} \mathrm{Cu}+0.16 \%$ to $+0.64 \%$, and $\delta^{66} \mathrm{Zn}+0.29 \%$ o to $+0.71 \%$ o ) of the KHF andesites, which are significantly different from those of the MORBs and the continental crust (CC), have a relatively wide range of $\mathrm{Cu}$ and $\mathrm{Zn}$ isotopic compositions. This is most likely to be a result of the entrainment of the sedimentary carbonate-derived components into an andesitic magma. The recycled altered rocks (higher $\delta^{56} \mathrm{Fe}$, lower $\delta^{66} \mathrm{Zn}$ ) could preferentially incorporate isotopically light Fe and heavy $\mathrm{Zn}$ into the magma, resulting in relative enrichment of the lighter Fe and heavier $\mathrm{Zn}$ isotopes in the andesites. The majority of the $\delta^{56} \mathrm{Fe}$ values in the KHF andesites are higher than those of the sediments and the local CC and lower than those of the subducted altered rocks, while the reverse is true for $\delta^{66} \mathrm{Zn}$, suggesting that the subseafloor sediments and $\mathrm{CC}$ materials (lower $\delta^{56} \mathrm{Fe}$, higher $\delta^{66} \mathrm{Zn}$ ) contaminating the rising andesitic magma could preferentially incorporate isotopically heavy Fe and light $\mathrm{Zn}$ into the magma, resulting in relative enrichment of the heavier Fe and lighter $\mathrm{Zn}$ isotopes in the andesites. Thus, the characteristics of the Fe and $\mathrm{Zn}$ isotopes in back-arc and island-arc volcanic rocks may also be influenced by the CC and plate subduction components.
\end{abstract}

Keywords: Fe-Cu-Zn isotope; seafloor andesite; Kueishantao hydrothermal field

\section{Introduction}

The stable isotopic systematics of iron, copper, and zinc (Fe-Cu-Zn) have been widely applied as tools for tracking fluid pathways and fingerprinting sources in volcanic and hydrothermal systems [1-7]. So far, only a few Fe-Cu-Zn isotope studies have been conducted on seafloor andesites. For example, the $\mathrm{Cu}$ isotopic composition $\left(\delta^{65} \mathrm{Cu}\right.$ values, +0.04 to $+0.38 \%$; avg. $0.12 \%, n=15$ ) of subduction-related andesites from a variety of locations worldwide, including two high-Mg andesites from Liaoxi in the North China Craton (NCC) [8], eight andesites from the Kamchatka [9,10], and two andesites from the Cordillera de Talamanca in the Central America arc [11], have been reported [5]. The 
andesites from the Eastern Volcanic Front (EVF) and the Sredinny Ridge (SR) have low $\mathrm{Sr} / \mathrm{Y}$ and high $\mathrm{Ba} / \mathrm{Th}$ ratios and are understood to contain a slab fluid component, while the andesites from the Northern Central Kamchatka Depression (NCKD) have high Sr/Y and low $\mathrm{Ba} / \mathrm{Th}$ ratios and are thought to contain a slab melt component [12]. Two andesites from Yixian have the $\delta^{65} \mathrm{Cu}$ values of +0.01 and $+0.05 \%$, respectively. The andesites from the Kamchatka and the Central American arcs have $\delta^{65} \mathrm{Cu}$ values ranging from +0.19 to $+0.28 \%$ [5]. Andesites also have variable $\mathrm{Cu}$ isotopic compositions similar to those of arc and continental basalts [5]. Given the significant $\delta^{65} \mathrm{Cu}$ range of arc and continental basalts, the $\mathrm{Cu}$ isotopic variations in andesites may reflect the isotopic heterogeneity of their parent magmas [5]. Savage et al. (2013) suggested that $\mathrm{Cu}$ isotopes can be fractionated towards heavy or light values, depending on the crystallizing phases [13]. Alternatively, the $\delta^{65} \mathrm{Cu}$ variations observed in andesites may be partially attributed to $\mathrm{Cu}$ isotope fractionation during magmatic differentiation [13]. Subduction-related andesites from various arc settings have $\mathrm{Cu}$ isotopic compositions similar to those of MORBs (mid-ocean ridge basalts) and OIBs (Ocean island basalts) [5]. A more detailed investigation into the arc lavas from Kamchatka is designed to cover a large across-arc region and thus a range of subduction fluid signatures related to slab dehydration and hydrous melting and to crystal-melt fractionation and magma mixing [9]. Two possible mechanisms may explain this observation: the isotopic heterogeneity of the arc mantle source and the slab fluids involved in melting or different degrees of partial melting [5].

The $\delta^{66} \mathrm{Zn}$ values $(+0.23$ to $+0.25 \%$ ) of andesite samples from the Merapi volcano, which is an andesitic stratovolcano located in central Java, are homogeneous, with a mean value of $+0.24 \%$ [14]. Any isotopic fractionation during magma degassing will not alter the bulk $\mathrm{Zn}$ isotopic composition of the magma, and the $\delta^{66} \mathrm{Zn}$ values of the Merapi andesites are the same as that of the magma source [14]. Both open- and closedsystem degassing calculations indicate that the degassing process does not significantly affect the $\mathrm{Zn}$ isotopic composition of the residual magma, which might partly explain the homogeneity of the previously reported $\mathrm{Zn}$ isotopic signatures of basalts [15,16]. Heavy $\mathrm{Zn}$ isotopes are enriched in solid deposits during gas condensation at the fumarole vents [14].

In this study, we present the first results of the $\mathrm{Fe}, \mathrm{Cu}$, and $\mathrm{Zn}$ isotope analyses of andesites from the Kueishantao hydrothermal field (KHF) off northeastern Taiwan, west Pacific (Figure 1). Our results attempt to show the characteristics of the $\mathrm{Fe}-\mathrm{Cu}-\mathrm{Zn}$ isotope compositions of andesite and its isotopic fractionation during magma evolution in the KHF.

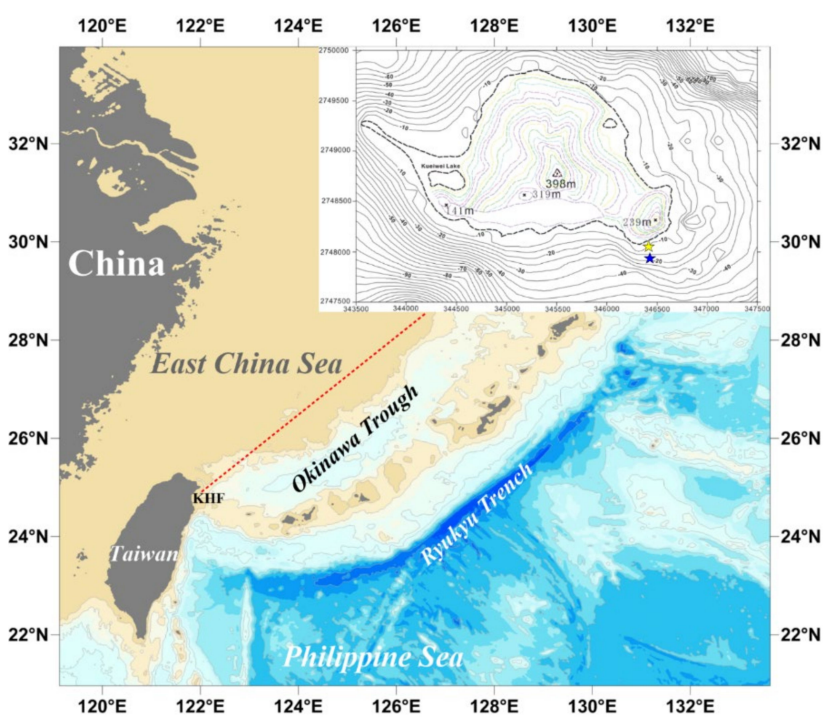

Figure 1. Locations of the andesite samples from the yellow and white spring vents in the Kueishantao hydrothermal field (KHF) analyzed for iron, copper, and zinc isotopic compositions in this study. Yellow star indicates yellow spring $\left(108^{\circ} \mathrm{C}\right)$, and blue star indicates white spring $\left(51^{\circ} \mathrm{C}\right)$. 


\section{Geological Setting}

The andesite samples are collected from the KHF at the southernmost part of the Okinawa Trough (SPOT), west Pacific (Figure 1). The KHF is a shallow-water hydrothermal field with $>30$ fluid vents at a water depth of 10-30 m in the southeast of the Kueishantao islet off the Ilan Plain [17-22]. The Kueishantao islet is located at a volcanic belt and is characterized by an andesite seafloor with lava and pyroclastics [21,23], located approximately just $100 \mathrm{~km}$ above the Wadati-Benioff zone; the continental crust (CC) remains intact (approximately $30 \mathrm{~km}$ thick) in the SPOT [24]. Some chemical analyses and petrographic studies of the volcanic rocks on the Kueishantao islet have been reported and major and trace element analyses were also carried out for 13 andesite samples from the Kueishantao islet [25]; the main volcanic activity on the Kueishantao islet occurred 7.0 $\pm 0.7 \mathrm{ka}$ off northeastern Taiwan in the SPOT [26].

\section{Samples and Methods}

The KHF, off the Ilan Plain, is hosted by an andesitic volcano [23]. It is the last volcanic center toward the southwest, along the spreading axis of the Okinawa Trough [25]. Six andesite samples were recovered from the KHF by divers on 31 May 2011. Table 1 and Figure 1 contain information about the sampling location, depth, and mineralogy of the volcanic rock samples. The fresh KHF andesite chips, including orthopyroxene and plagioclase, were powdered (200 mesh in size) using an agate mortar for isotopic analyses.

Table 1. Sampling locations of the andesites from the Kueishantao hydrothermal field.

\begin{tabular}{cccc}
\hline Sample No. & Latitude & Longitude & Water Depth $(\mathbf{m})$ \\
\hline K11-W0-R1-2 & $24.83412^{\circ} \mathrm{N}$ & $121.96196^{\circ} \mathrm{E}$ & 15.1 \\
K11-W0-R2-2 & $24.83412^{\circ} \mathrm{N}$ & $121.96196^{\circ} \mathrm{E}$ & 15.1 \\
K11-W5-R1-2 & $24.83412^{\circ} \mathrm{N}$ & $121.96196^{\circ} \mathrm{E}$ & 15.1 \\
K11-W5-R2-2 & $24.83412^{\circ} \mathrm{N}$ & $121.96196^{\circ} \mathrm{E}$ & 15.1 \\
K11-Y5-R1-2 & $24.8349^{\circ} \mathrm{N}$ & $121.96194^{\circ} \mathrm{E}$ & 7.2 \\
K11-Y5-R2-2 & $24.8349^{\circ} \mathrm{N}$ & $121.96194^{\circ} \mathrm{E}$ & 7.2 \\
\hline
\end{tabular}

\section{1. $\mathrm{Fe}, \mathrm{Cu}$, and $\mathrm{Zn}$ Isotope Analytical Methods}

$\mathrm{The} \mathrm{Fe}, \mathrm{Cu}$, and $\mathrm{Zn}$ isotopic ratios of the andesites were measured on $\mathrm{Nu}$ Plasma II multiple collector-inductively coupled plasma-mass spectrometer (MC-ICP-MS, Nu Instruments, Wrexham, UK) at the Université Libre de Bruxelles (ULB, Laboratoire G-Time), Brussels, Belgium. The dissolution, the $\mathrm{Fe}, \mathrm{Cu}$, and $\mathrm{Zn}$ purifications, and the isotopic analyses were undertaken using the established procedure described in $[27,28]$, but slightly modified, as described by [29]. In brief, the powder samples (approximately $50 \mathrm{mg}$ for the bulk rocks) were dissolved in closed screw-top Savillex Teflon beakers using a doubledistilled concentrated $\mathrm{HF}-\mathrm{HNO}_{3}-\mathrm{HCl}$ mixture for a minimum period of approximately 3 days at $125^{\circ} \mathrm{C}$. After complete dissolution, $1 \mathrm{~mL} 8 \mathrm{~N} \mathrm{HCl}+0.001 \% \mathrm{H}_{2} \mathrm{O}_{2}$ was added to the beaker and then heated to dryness at $80^{\circ} \mathrm{C}$. This process was repeated two or three times to ensure that all the cations were converted into chloride species. The final residues were dissolved in $1 \mathrm{~mL} 8 \mathrm{~N} \mathrm{HCl}+0.001 \% \mathrm{H}_{2} \mathrm{O}_{2}$ in preparation for ion exchange separation. $\mathrm{The} \mathrm{Fe}, \mathrm{Cu}$, and $\mathrm{Zn}$ in the samples were separated from the sample matrix constituents (e.g., $\mathrm{Ti}, \mathrm{Cr}$, and $\mathrm{Mg}$ ) using an anion exchange resin (Bio-Rad AG1-X8, 100 to 200 mesh) in an $\mathrm{HCl}$ medium. A second passage for the $\mathrm{Cu}$ and $\mathrm{Zn}$ was preferred to avoid any spectral or non-spectral interference from potential residual matrix elements during the isotopic analysis.

\subsection{1. $\mathrm{Cu}$ and $\mathrm{Zn}$ Isotope Analyses}

The $\mathrm{Cu}$ and $\mathrm{Zn}$ isotopic ratios were measured using the doping method with the addition of a JMC Zn (Art. Nr 13835, lot Nr 0620611.10, 'Zn110') or Cu (Art. Nr 13867, lot $\mathrm{Nr}$ 13.0140203.10, 'Cu310') in-house standard solution and the sample-standard bracketing technique [27]. The isotopic determinations were carried out in wet plasma mode for 
the $\mathrm{Zn}$ and $\mathrm{Cu}$ in the andesites and were analyzed under higher sensitivity dry plasma conditions by means of an ESL Apex-Q desolvator (Elemental Scientific, Omaha, NE, USA), owing to their lower concentrations. The solution concentrations for the measurements were $400 \mu \mathrm{g} / \mathrm{L} \mathrm{Zn} \mathrm{(wet} \mathrm{plasma)} \mathrm{and} 100 \mu \mathrm{g} / \mathrm{L} \mathrm{Zn} \mathrm{or} \mathrm{Cu} \mathrm{(dry} \mathrm{plasma),} \mathrm{in} 0.05 \mathrm{~mol} / \mathrm{L}$ $\mathrm{HNO}_{3}$. To monitor the accuracy of the analyses and report the data, the SRM NIST 976 $\mathrm{Cu}$ and Lyon JMC 3-0749L Zn reference solutions were measured, as was the IRMM $3702 \mathrm{Zn}$ certified reference material [30]. The $\mathrm{Cu}$ and $\mathrm{Zn}$ isotopic data are reported in standard $\delta$ notation in per-mil against the international reference materials SRM NIST 976 and JMC 3-0749L, respectively: $\delta^{65} \mathrm{Cu}=\left[\left({ }^{65} \mathrm{Cu} /{ }^{63} \mathrm{Cu}\right)_{\text {sample }} /\left({ }^{65} \mathrm{Cu} /{ }^{63} \mathrm{Cu}\right)_{\text {NIST } 976}-1\right]$ $\times 1000$ and $\delta^{\mathrm{i}} \mathrm{Zn}=\left[\left({ }^{\mathrm{i}} \mathrm{Zn} /{ }^{64} \mathrm{Zn}\right)^{\text {sample }} /\left({ }^{\mathrm{i}} \mathrm{Zn} /{ }^{64} \mathrm{Zn}\right)_{\mathrm{JMC}} 3-0749 \mathrm{~L}-1\right] \times 1000$, where i refers to 66 or 68 . Repeated measurements of the in-house JMC Cu110 and Zn310 solutions yielded average values of $0.00 \pm 0.04 \%$ o (2SD) $(n=30)$ for the $\delta^{65} \mathrm{Cu}_{110}$ and $0.00 \pm 0.07 \%$ (2SD) $(n=31)$ for the $\delta^{66} \mathrm{Zn}_{310}$. The Cu $\mathrm{u}_{\mathrm{NIST}}$ yielded $\delta^{65} \mathrm{Cu}_{110}=-0.97 \pm 0.13 \%$ (2SD)

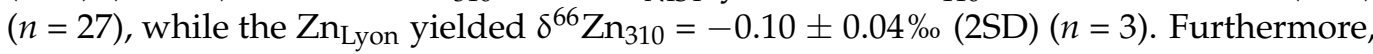
the IRMM 3702 yielded $\delta^{66} \mathrm{Zn}_{310}=-0.41 \pm 0.07 \%$ o (2SD) $(n=11)$, which, relative to the $\mathrm{Zn}$ Lyon, would give $\delta^{66} \mathrm{Zn}_{\text {Lyon }}=-0.31 \pm 0.07 \%$ o $(2 \mathrm{SD})(n=11)$. This was in excellent agreement with the result of, for example, Moeller et al. (2012) and Petit et al. (2008), who reported $\delta^{66} \mathrm{Zn}_{\text {Lyon }}=-0.29 \pm 0.05 \%$ o (2SD) $(n=5)$ and $\delta^{66} \mathrm{Zn}_{\text {Lyon }}=-0.32 \pm 0.04 \%$ (2SD) $(n=4)[27,31]$. The details of the analytical session conditions and mass bias corrections were presented in [27] and, more recently, in [29].

\subsubsection{Fe Isotope Analyses}

The Fe isotope analysis was carried out on a Nu Plasma II in dry plasma and in medium resolution. A DSN-100 desolvator (Nu Instruments, Wrexham, UK) was used for the dry plasma conditions. The solution concentrations for the measurements were $800 \mu \mathrm{g} / \mathrm{L} \mathrm{Fe}$ and $1000 \mu \mathrm{g} / \mathrm{L} \mathrm{Ni}$ in $0.05 \mathrm{~mol} / \mathrm{L} \mathrm{HNO}_{3}$. Two isotopic ratios were measured $\left({ }^{56} \mathrm{Fe} /{ }^{54} \mathrm{Fe}\right.$ and $\left.{ }^{57} \mathrm{Fe} /{ }^{54} \mathrm{Fe}\right)$ by applying the sample-standard bracketing method by means of IRMM 014 and external normalization, using $\mathrm{Ni}$ as a dopant. The data were reported in delta $(\delta)$ notation relative to the IRMM-014 standard [32], calculated as $\delta^{\mathrm{i}} \mathrm{Fe}=\left[\left({ }^{\mathrm{i}} \mathrm{Fe} /{ }^{54} \mathrm{Fe}\right)_{\text {sample }} /\left({ }^{\mathrm{i}} \mathrm{Fe} /{ }^{54} \mathrm{Fe}\right)_{\text {IRMM- } 014}-1\right] \times 1000$, where i refers to 56 or 57 . Accuracy and precision were assured by analysis of the reference material IRMM-014 as the bracketing standard and our in-house quality control standard 'MIX'. The mean Fe isotope compositions of these standards were: IRMM-014: $\delta^{56} \mathrm{Fe}=0.00 \pm 0.07 \% ; \delta^{57} \mathrm{Fe}=0.01 \pm 0.09 \%$ o (2SD, $n=68)$; MIX: $\delta^{56} \mathrm{Fe}=-1.55 \pm 0.11 \%$; $\delta^{57} \mathrm{Fe}=-2.26 \pm 0.16 \%$ (2SD, $n=61$ ). The long-term average (2014 to 2016) of the MIX standard was $\delta^{56} \mathrm{Fe}=-1.55 \pm 0.10 \%$; $\delta^{57} \mathrm{Fe}=-2.28 \pm 0.16 \%$ o $(2 \mathrm{SD}, n=126)$.

\section{Results}

The Fe, $\mathrm{Cu}$, and $\mathrm{Zn}$ isotopic data of the andesites are shown in Table 2. The $\delta^{56} \mathrm{Fe}$ values in the $\mathrm{KHF}$ andesites show a large range ( 0.02 to $0.22 \%$; avg. $0.09 \%$, $n=8$ ) (Figure 2 ). One KHF andesite sample possesses an $\delta^{56} \mathrm{Fe}$ value $(0.22 \pm 0.02 \%$ in K11-Y5-R2-2; Table 2) that is significantly higher than those of the MORBs [33] (Figure 2). 
Table 2. Fe-Cu-Zn isotopic composition of the andesites from the Kueishantao hydrothermal field.

\begin{tabular}{|c|c|c|c|c|c|c|c|c|c|c|c|c|c|}
\hline Sample Name & $\delta^{56} \mathrm{Fe}$ & 2SD & $\delta^{57} \mathrm{Fe}$ & 2SD & $\mathbf{N}$ & $\delta^{65} \mathrm{Cu}$ & 2SD & $\mathbf{N}$ & $\delta^{68} \mathrm{Zn}$ & 2SD & $\delta^{66} \mathrm{Zn}$ & 2SD & $\mathbf{N}$ \\
\hline K11-W0-R1-2 & 0.08 & 0.05 & 0.1 & 0.09 & 4 & 0.33 & 0.07 & 3 & 1.07 & 0.14 & 0.49 & 0.07 & 3 \\
\hline K11-W0-R2-2 & 0.02 & 0.08 & 0.06 & 0.1 & 3 & 0.46 & 0.07 & 3 & 0.85 & 0.04 & 0.39 & 0.06 & 2 \\
\hline K11-W0-R2-2 a & 0.02 & 0.08 & 0.04 & 0.02 & 3 & 0.33 & 0.1 & 3 & 0.66 & 0.03 & 0.29 & 0.04 & 2 \\
\hline K11-W5-R1-2 & 0.08 & 0.07 & 0.13 & 0.11 & 6 & 0.34 & 0.03 & 3 & 1.55 & 0.07 & 0.71 & 0 & 2 \\
\hline K11-W5-R2-2 & 0.11 & 0.1 & 0.15 & 0.05 & 3 & 0.64 & 0.06 & 3 & 0.82 & 0.1 & 0.36 & 0.04 & 2 \\
\hline K11-Y5-R1-2 & 0.08 & 0.02 & 0.11 & 0.05 & 3 & 0.29 & 0.08 & 3 & 1.09 & 0.15 & 0.46 & 0.1 & 2 \\
\hline K11-Y5-R1-2 a & 0.1 & 0.03 & 0.13 & 0.11 & 3 & 0.24 & 0.04 & 3 & 0.9 & 0.16 & 0.43 & 0.01 & 2 \\
\hline K11-Y5-R2-2 & 0.22 & 0.02 & 0.34 & 0.11 & 3 & 0.16 & 0.06 & 3 & 0.68 & 0.21 & 0.34 & 0.06 & 2 \\
\hline \multicolumn{14}{|l|}{ Reference materials } \\
\hline IRMM-014 & 0.00 & 0.08 & 0.01 & 0.10 & 43 & & & & & & & & \\
\hline MIX & -1.55 & 0.09 & -2.27 & 0.13 & 29 & & & & & & & & \\
\hline Average Quality control 'Mix' on Nu Plasma I & -1.53 & 0.07 & -2.26 & 0.15 & 6 & & & & & & & & \\
\hline JMC Cu110 in-house solutions & & & & & & 1.06 & 0.16 & 30 & & & & & \\
\hline SRM NIST $976 \mathrm{Cu}$ & & & & & & -0.97 & 0.13 & 27 & & & & & \\
\hline BHVO-2 & & & & & & 0.00 & 0.07 & 9 & & & & & \\
\hline JMC Zn310 in-house solutions & & & & & & & & & -0.20 & 0.10 & -0.10 & 0.06 & 20 \\
\hline IRMM-3702 Zn & & & & & & & & & 0.63 & 0.16 & 0.32 & 0.08 & 8 \\
\hline
\end{tabular}

"a" represents a duplicate sample.

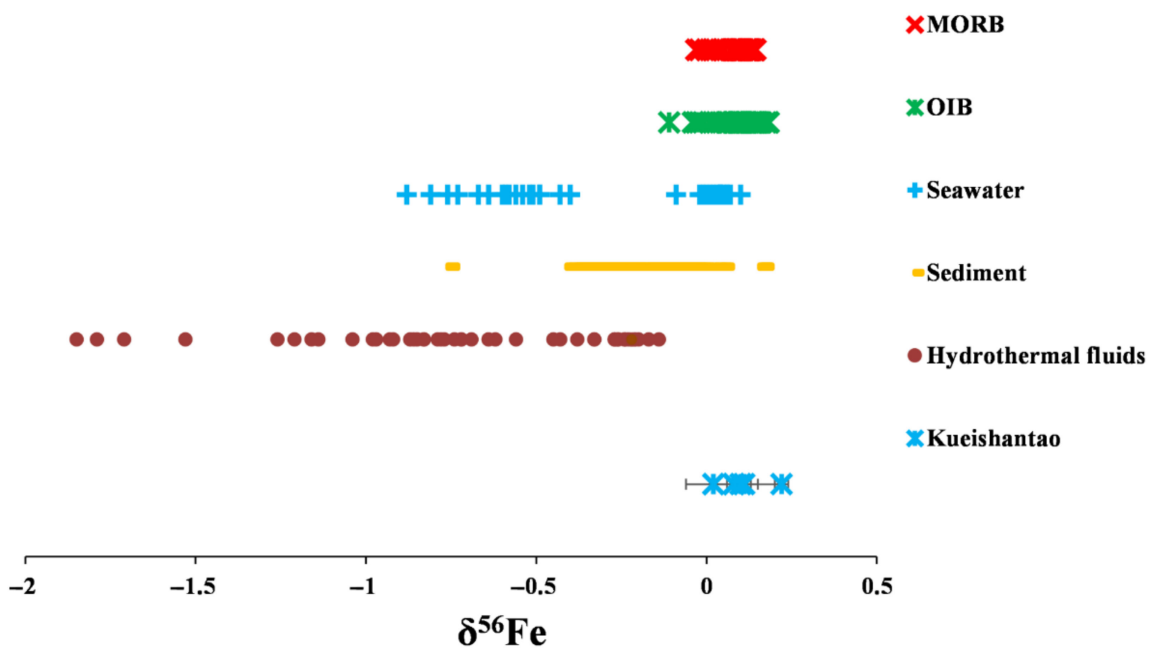

Figure 2. The $\delta^{56} \mathrm{Fe}$ distribution of KHF andesites. For comparison, the $\delta^{56} \mathrm{Fe}$ range of MORBs [33], OIB [33,34], seawater [35], sediment [36,37], and hydrothermal fluids [1,37-39] are also shown.

The $\delta^{65} \mathrm{Cu}$ values in the $\mathrm{KHF}$ andesites show a large range $(0.16$ to $0.64 \%$; avg. $0.35 \%$, $n=8)$ and all are significantly higher than those of MORBs $(0.07 \pm 0.06 \%$; Figure 3$)[5,40]$.

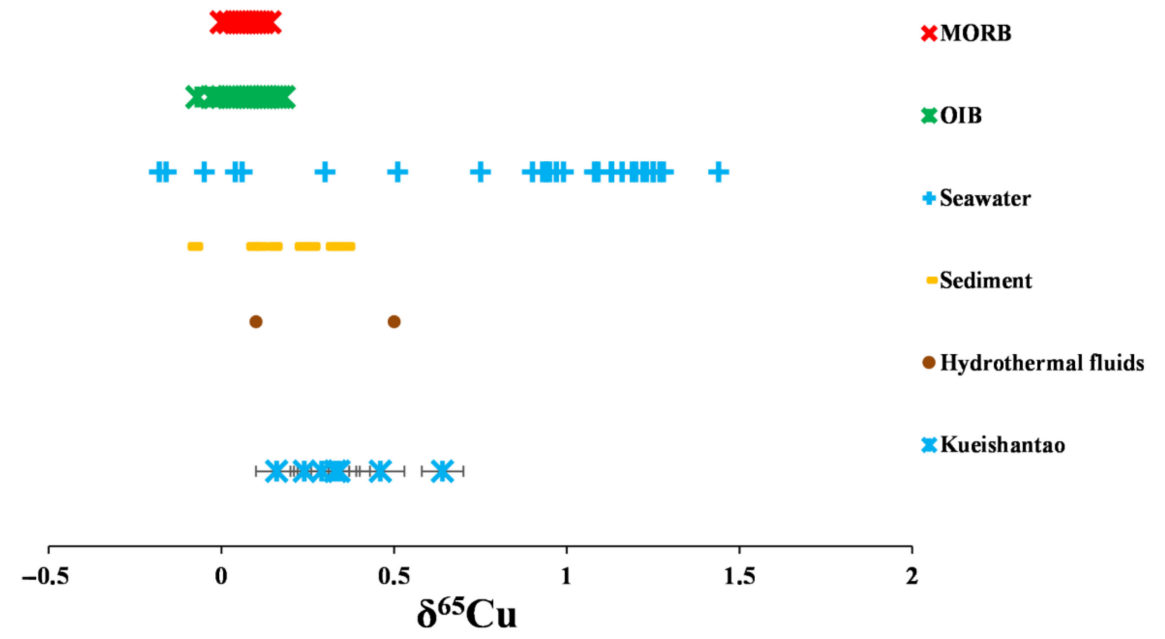

Figure 3. The $\delta^{65} \mathrm{Cu}$ distribution of KHF andesites. For comparison, the $\delta^{65} \mathrm{Cu}$ range of MORB $[5,40]$, OIB [5,40], seawater [41,42], sediment [15], and hydrothermal fluids [43] are also shown. 
For KHF andesites, the $\delta^{66} \mathrm{Zn}$ values show a large range $(0.29$ to $0.71 \%$; avg. $0.43 \%$, $n=8)$, with one abnormally high value $(0.71 \%$ o $\pm 0.00 \%$ ) in K11-W5-R1-2 (Figure 4$)$.

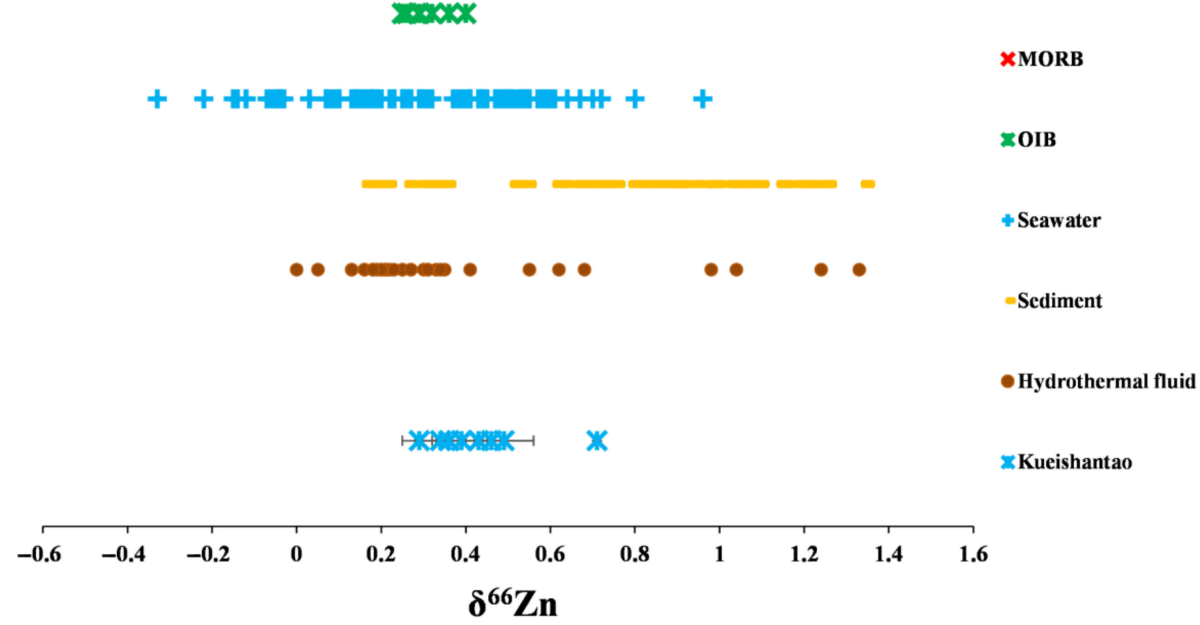

Figure 4. The $\delta^{66} \mathrm{Zn}$ distribution of KHF andesites. For comparison, the $\delta^{66} \mathrm{Zn}$ range of MORB [44-46], OIB [46], seawater [42,47,48], sediment [15,49], and hydrothermal fluids [6] are also shown.

Furthermore, the majority of $\delta^{56} \mathrm{Fe}$ and $\delta^{57} \mathrm{Fe}$ values in the KHF andesites were higher than those in the sediments (see Figure 2) and the Taiwan local CC (Table 3) and lower than those in the subducted altered rocks (with heavier Fe and lighter $\mathrm{Zn}$ isotopic compositions) $[1,36,50-54]$, while the reverse was true for $\delta^{66} \mathrm{Zn}$ and $\delta^{68} \mathrm{Zn}$.

Table 3. The inverse calculation of Fe-Cu-Zn isotope compositions of the Taiwan local continental crust.

\begin{tabular}{|c|c|c|c|c|c|c|c|c|c|c|}
\hline \multirow{2}{*}{ Samples } & \multicolumn{3}{|c|}{ Kueishantao Andesite } & \multicolumn{3}{|c|}{ MORB $^{a}$} & \multirow{2}{*}{$\mathbf{f}_{\mathrm{CC}} \mathbf{b}$} & \multicolumn{3}{|c|}{$\mathrm{CC}$} \\
\hline & $\delta^{56} \mathrm{Fe}$ & $\delta^{65} \mathrm{Cu}$ & $\delta^{66} \mathrm{Zn}$ & $\delta^{56} \mathrm{Fe}$ & $\delta^{65} \mathrm{Cu}$ & $\delta^{66} \mathrm{Zn}$ & & $\delta^{56} \mathrm{Fe}$ & $\delta^{65} \mathrm{Cu}$ & $\delta^{66} \mathrm{Zn}$ \\
\hline K11-W0-R1-2 & 0.08 & 0.33 & 0.49 & 0.105 & 0.07 & 0.28 & 0.3 & 0.02 & 0.94 & 0.98 \\
\hline K11-W0-R2-2 & 0.02 & 0.46 & 0.39 & 0.105 & 0.07 & 0.28 & 0.3 & -0.18 & 1.37 & 0.65 \\
\hline K11-W5-R1-2 & 0.08 & 0.34 & 0.71 & 0.105 & 0.07 & 0.28 & 0.3 & 0.02 & 0.97 & 1.71 \\
\hline K11-W5-R2-2 & 0.11 & 0.64 & 0.36 & 0.105 & 0.07 & 0.28 & 0.3 & 0.12 & 1.97 & 0.55 \\
\hline K11-Y5-R1-2 & 0.08 & 0.29 & 0.46 & 0.105 & 0.07 & 0.28 & 0.3 & 0.02 & 0.80 & 0.88 \\
\hline K11-Y5-R2-2 & 0.22 & 0.16 & 0.34 & 0.105 & 0.07 & 0.28 & 0.3 & 0.49 & 0.37 & 0.48 \\
\hline
\end{tabular}

a Average $\delta^{56} \mathrm{Fe}, \delta^{65} \mathrm{Cu}, \delta^{66} \mathrm{Zn}$ isotope compositions of MORB were from $[5,33,45] .{ }^{\mathrm{b}}$ Ratio of continental crust mixing (fCC) were from [25].

\section{Discussion}

\subsection{Fe-Cu-Zn Isotopic Fractionations during Magma Evolution}

\subsubsection{Fe Isotopes}

The $\delta^{56}$ Fe value $(0.22 \pm 0.02 \%$ of the K11-Y5-R2-2 andesite sample is significantly higher than those of previously studied MORBs $(+0.04$ to $+0.14 \%$ o $)[33,55]$, hydrothermal fluids $(-0.18$ to $-1.84 \%$ ) $[1,37-39]$, seawater $(-0.88$ to $+0.10 \%$ ) [35], and sediments [36,37] (Figure 2), indicating that Fe isotopic fractionation may occur during the magmatic processes, including partial melting of the MORB-type mantle, fractional crystallization of the basaltic melt, plate subduction, and crustal contamination. This suggests that during magma evolution, the isotopically heavy Fe may be preferentially incorporated into the andesitic melts. However, the majority of the $\delta^{56} \mathrm{Fe}$ values $(+0.02 \%$ o to $+0.11 \%$ o) in the KHF andesites were consistent with those of the MORBs. This suggests that the Fe in the KHF andesites is mainly from the andesitic magma, which originated from an MORB-type man- 
tle [25], and implies that there is insignificant Fe isotope fractionation during the magma evolution from MORB-type mantle to andesitic melt.

\subsubsection{Cu Isotopes}

The $\mathrm{Cu}$ isotopic compositions of the KHF andesite samples exhibit significantly larger variations $(0.16 \%$ to $0.64 \%$, Table 2$)$ than those of the previously studied MORBs (0 to $+0.14 \%$ ) [5,40]. These values are also higher than those of the previously studied OIBs $(-0.07$ to $+0.18 \%$ o $[5,40]$, sediments [15], and hydrothermal fluids [43] (Figure 3), implying that during magma evolution the isotopically heavy $\mathrm{Cu}$ could preferentially incorporate into the andesitic magma, resulting in the relative enrichment of the heavier $\mathrm{Cu}$ isotopes in andesites.

\subsubsection{Zn Isotopes}

The $\mathrm{Zn}$ isotopic values of the studied KHF andesite samples range from +0.29 to $+0.71 \%$, which significantly exceeds the $\delta^{66} \mathrm{Zn}$ range of the previously reported MORBs $(+0.26$ to $+0.30 \%)$ [46] and is lower on average than those of the previously studied seawater $[42,47,48]$ and sediments [15,49] (Figure 4). This implies that the andesitic magma evolution processes may have caused $\mathrm{Zn}$ isotopic fractionation. Due to the KHF andesitic magma being formed from an MORB-type mantle [25], the heavy $\mathrm{Zn}$ isotopes $\left({ }^{66} \mathrm{Zn}\right.$ and ${ }^{68} \mathrm{Zn}$ ) were more likely to be incorporated into the andesitic melt than into the basaltic melt.

However, the sedimentary carbonates exhibit substantially heavier $\mathrm{Zn}$ isotopic compositions (up to $+1.34 \%$ ) $[49,56]$ compared to those of the studied KHF andesites $(+0.29$ to $+0.71 \%$ ), and the recycling of sedimentary carbonates into the mantle may result in elevated $\delta^{66} \mathrm{Zn}$ values, which have been observed in continental basalts in eastern China [57]. Moreover, certain highly evolved silica-rich rocks (e.g., pegmatites or sediments) may exhibit high $\delta^{66} \mathrm{Zn}$ values $(+0.53$ to $+0.88 \%$ ) [58]. Therefore, plate subduction and crustal contamination with sediment injection may be responsible for the heavier $\delta^{66} \mathrm{Zn}$ values of the KHF andesites compared to those of the MORB-type mantle and basalt.

\subsection{Fe-Cu-Zn Isotope Heterogeneities in the Taiwan Continental Crust \\ 5.2.1. Fe-Cu-Zn Isotope Composition of Taiwan Continental Crust}

According to the primitive mantle-normalized trace element and chondrite-normalized rare earth element patterns of the KHF andesites (Figure 5), we can see that all the samples share the same element distribution patterns with the CC [25]. Chen et al. reported the isotopic ( $\mathrm{Nd}, \mathrm{Sr}, \mathrm{O})$ and chemical compositions of fresh andesites from Kueishantao [25]. All the andesites samples, including the samples in this study and those reported by Chen et al. [25], have uniform chemical compositions, which means they were derived from the same magma source and had similar magma evolution [59-61]. These rocks reveal extremely low $\mathrm{Nd}$ isotopic values $(\varepsilon \mathrm{Nd}=-1.9$ to -5.2$)$, very high $\mathrm{Sr}$ isotopic values $\left({ }^{87} \mathrm{Sr} /{ }^{86} \mathrm{Sr}>0.705\right)$, and high $\delta^{18} \mathrm{O}(7 \sim 8 \%$ ) [25]. Such a strong continental signature of Kueishantao can be explained by crustal contamination, most likely the magma resulting from MORB-type magma assimilation with about 30\% local CC materials and/or the thick overlying sediments [25]. If the model of the two-end-member mixing of MORBtype magma and Taiwan local CC, which are best represented by Taiwan granitoids and metasediments [62,63], as reported by Chen et al. (1995) [25], can truly explain the origin of the KHF andesites, we can use the estimated ratios of $\mathrm{CC}$ mixing $\left(\mathrm{f}_{\mathrm{CC}}\right)$ to inversely infer the $\mathrm{Fe}-\mathrm{Cu}-\mathrm{Zn}$ isotope composition in the enriched CC according to a simple two-end-membermixing model: $\mathrm{I}_{\text {Kueishantao }}=\mathrm{I}_{\mathrm{CC}} \cdot \mathrm{f}_{\mathrm{CC}}+\mathrm{I}_{\mathrm{MORB}} \cdot\left(1-\mathrm{f}_{\mathrm{CC}}\right)$, where "I" refers to $\delta^{56} \mathrm{Fe}, \delta^{65} \mathrm{Cu}$, or $\delta^{66} \mathrm{Zn}$ and "I Kueishantao", "I $\mathrm{ICC}_{\mathrm{CC}}$, and "I $\mathrm{I}_{\mathrm{MORB}}$ " are the isotope values of the KHF andesites, continental crust and MORB, respectively. The results of the calculations and all of the parameters are listed in Table 3. It is noticed that one exceptional sample (K11-Y5-R2-2) has the highest $\delta^{56} \mathrm{Fe}$ and the lowest $\delta^{65} \mathrm{Cu}$ and $\delta^{66} \mathrm{Zn}$ among the studied KHF andesites, which may have suffered from little mixing of the CC and should be excluded during the calculation. Therefore, we can plausibly estimate that the CC materials have the large 
range of $\delta^{56} \mathrm{Fe}(-0.18 \sim 0.12 \%), \delta^{65} \mathrm{Cu}\left(0.80 \sim 1.97 \%\right.$ ) , and $\delta^{66} \mathrm{Zn}(0.55 \sim 1.71 \%$ ) , respectively. The calculated values may not be very precise but are sufficient to demonstrate that the contaminated crust source of the KHF magma was much more enriched in $\delta^{65} \mathrm{Cu}$ and $\delta^{66} \mathrm{Zn}$ than the typical MORB-type mantle source, but slightly depleted in $\delta^{56} \mathrm{Fe}$. The large variation of calculated isotope compositions (from the perspectives of the $\mathrm{Fe}-\mathrm{Cu}$ $\mathrm{Zn}$ isotopes) suggests that a rather heterogeneous $\mathrm{CC}$ exists during the mantle-derived magma differentiation.
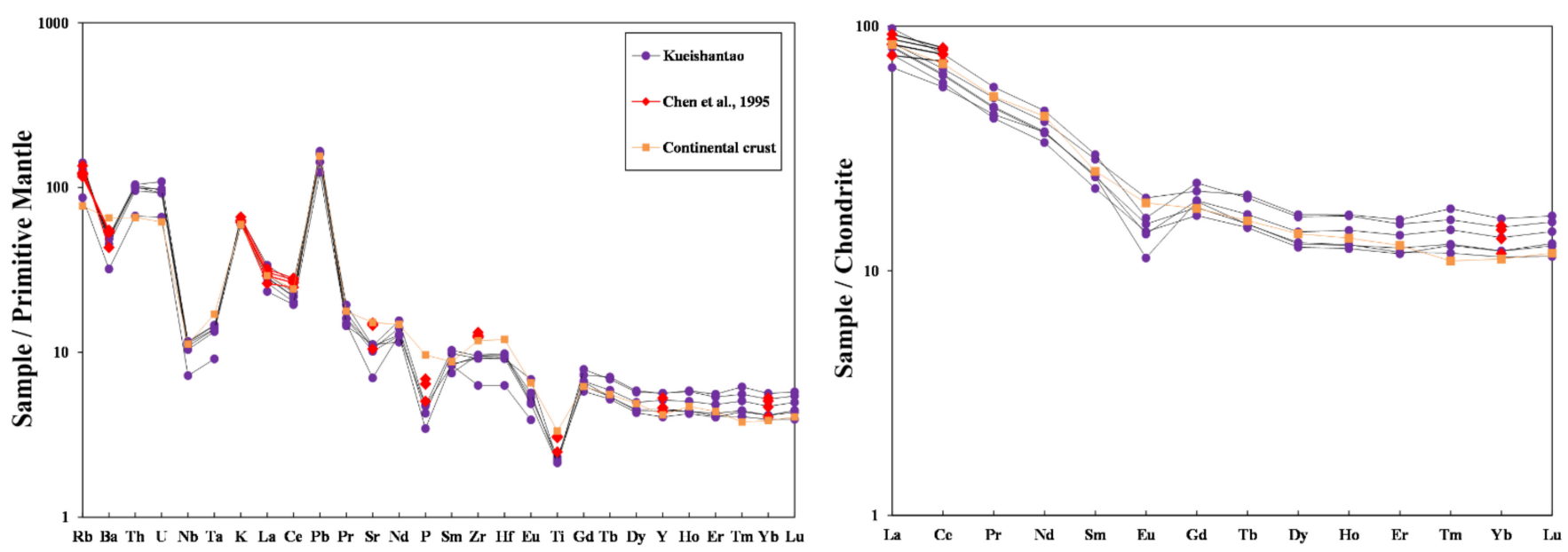

Figure 5. Trace element patterns normalized to primitive mantle concentrations and REE patterns normalized to chondritic values for KHF volcanic rocks from [25] and this work. The primitive mantle and chondrite data are from [64]. The data of CC are from [65].

5.2.2. Sources Controlling Fe-Cu-Zn Isotope Heterogeneities in the Taiwan Continental Crust

The Kueishantao is located on the tip segment of the Okinawa Trough, within the Asian continental lithosphere, near the convergent margin of the Ryukyu subduction system. The CC of the Kueishantao area does not show significant thinning, with the crustal thickness being around $30 \mathrm{~km}[66,67]$, which is similar to the crust thickness of the Eurasian continental shelf crust. Unlike the Okinawa Trough, which belongs to the onset of the "drifting" stage during the evolution of back-arc basins ("doming-riftingdrifting"; [23,68]) and suffered less than $10 \%$ of the CC materials involved in the magma generation $[25,60]$, the Kueishantao, on the point of entering the "rifting" stage, has suffered a larger degree of influence by the CC materials [25]. Back-arc basin basalts (BABB) have similar Fe isotope compositions to MORBs $(+0.07 \%$ to $+0.14 \%)$; for example, BABBs from the North Fiji basin have $\delta^{56} \mathrm{Fe}$ ranging from $+0.09 \%$ to $+0.11 \%$ [33], which may suggest little influence by the CC materials. Inversely, a large amount of CC material has been involved in the magma generation at Kueishantao, as mentioned in the above discussion. It may be the key to explaining the enriched $\delta^{65} \mathrm{Cu}$ and $\delta^{66} \mathrm{Zn}$ and the depleted $\delta^{56} \mathrm{Fe}$ in the KHF andesites. Seawater has an $\delta^{56} \mathrm{Fe}$ value of $-0.88 \sim 0.1 \%$ [35], a $\delta^{65} \mathrm{Cu}$ value of $-0.18 \sim 1.44 \%$ o [41,42], and a $\delta^{66} \mathrm{Zn}$ value of $-0.33 \sim 0.96 \%$ [ $\left.42,47,48\right]$. Hydrothermal vent fluids for seafloor sulfide-sulfate mineralization typically have $\delta^{56} \mathrm{Fe}$ values ranging from $-1.85 \%$ to $-0.14 \%$ o [1,37-39], a $\delta^{65} \mathrm{Cu}$ value of $0.3 \pm 0.2 \%$ [43], and a $\delta^{66} \mathrm{Zn}$ value of $0 \sim 1.33 \%$ [6]. Sediment from the ocean has $\delta^{56} \mathrm{Fe}$ from $-0.76 \%$ to $0.16 \%$ [36], $\delta^{65} \mathrm{Cu}$ from $-0.09 \%$ to $0.35 \%$ [ [15], and $\delta^{66} \mathrm{Zn}$ from $0.16 \%$ to $1.34 \%$ [15,49]. Seawater, hydrothermal vent fluids, and sediment can have lower $\delta^{56} \mathrm{Fe}$ and higher $\delta^{65} \mathrm{Cu}$ and $\delta^{66} \mathrm{Zn}$ than those of MORBs, which can be the candidates to change the isotope compositions of KHF andesites when the andesitic magma ascends through the CC. However, seawater and hydrothermal vent fluid alterations were insignificant in the KHF andesites, and no secondary alteration minerals were found in the rock thin sections. 
As mentioned above, Taiwan granitoids and metasediments are the best representatives of Taiwan local CC $[62,63]$. Although the Fe-Cu-Zn isotope compositions of the Taiwan granitoid are unknown, they can be assumed from the published granitoid data around the world. Poitrasson and Freydier analyzed bulk granitic rocks, and the $\delta^{56} \mathrm{Fe}$ of granitoids can reach $+3.9 \%$ [ [69], which is significantly heavier than the MORBs and KHF andesites $(0.02 \%$ o to $0.22 \%$ o $)$. Li et al. reported $\mathrm{Cu}$ isotope compositions of granites from the Lachlan Fold Belt, SE Australia, and showed that the $\delta^{65} \mathrm{Cu}$ of I-type granites and S-type granites are $0.03 \pm 0.15 \%$ o and $-0.03 \pm 0.42 \%$, respectively [70]. This is obviously lower than the $\delta^{65} \mathrm{Cu}$ of the KHF andesites $(0.16 \sim 0.64 \%$ ). The $\mathrm{Zn}$ isotope compositions of granodiorite and granite from Cameroon are $0.41 \%$ and $0.47 \%$, respectively [71], similar to the values of the KHF andesites $(0.34 \sim 0.71 \%$ ). This makes Taiwan granitoid insufficient to be an end-member. Rouxel et al. reported that carbonate-rich sediments have Fe isotope compositions significantly less than the igneous value (down to $-1.12 \%$ ), and the carbonate shows a tendency towards enrichment in the heavy $\mathrm{Cu}$ isotope (up to $+15.85 \%$ ) $[36,72,73]$. Furthermore, sedimentary carbonates have much heavier Zn isotopic compositions (up to +1.34\%o) [49], which can explain the elevated $\delta^{66} \mathrm{Zn}$ values in continental basalts from eastern China [57]. Therefore, sedimentary carbonates should be one of the reasonable end-members needed to explain the observed Fe-Cu-Zn isotope anomaly of KHF andesites. To further verify the possibility of contribution of sedimentary carbonates (calcite/aragonite, dolomite, and magnesite are three major carbonate minerals; [57]) to the magma, we completed two-endmember-mixing modeling between the MORB and the sedimentary carbonates (Figure 6). The modeling suggests that the carbonates may be contributing high $\delta^{65} \mathrm{Cu}$ and $\delta^{66} \mathrm{Zn}$ values for the KHF andesites, and the deep marine carbonate (e.g., dolomite) cycling in the Earth's mantle can also be traced using the $\mathrm{Cu}$ and $\mathrm{Zn}$ isotopes [57].
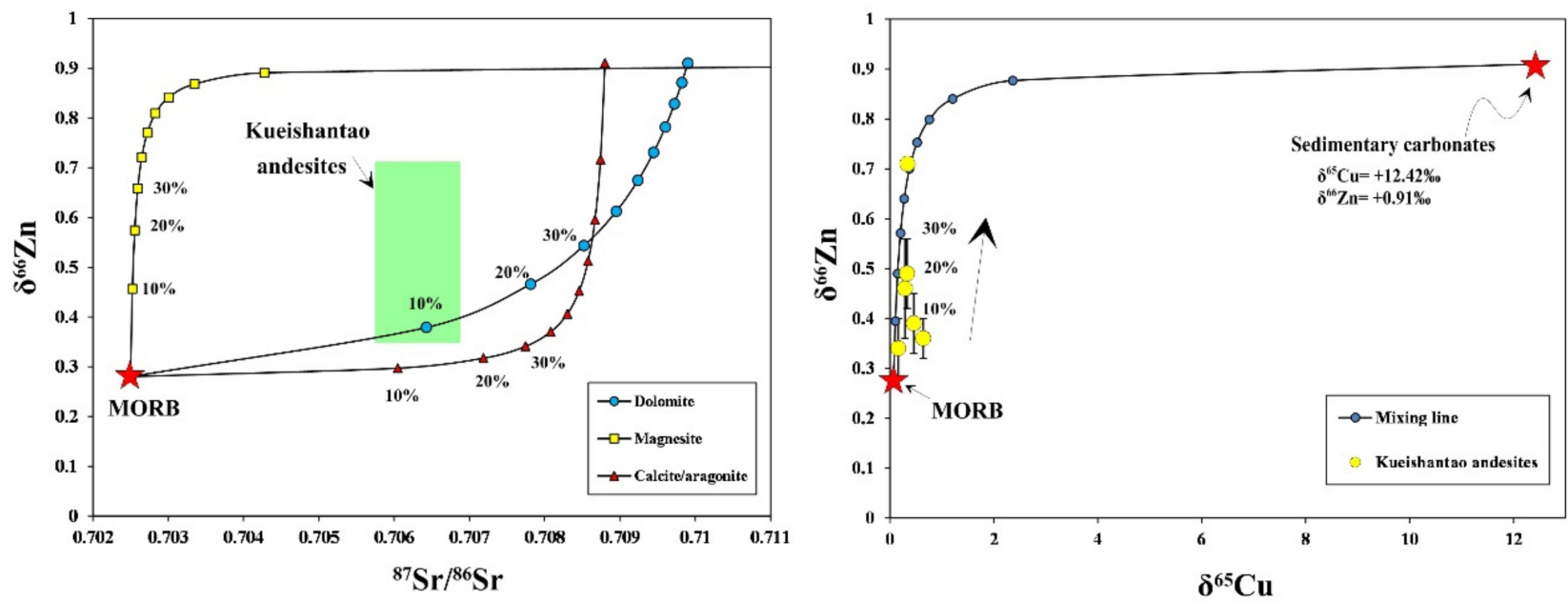

Figure 6. The data of $\mathrm{Zn}$ isotopic composition, the $\mathrm{Zn}$ and $\mathrm{Sr}$ contents, and the ${ }^{87} \mathrm{Sr} /{ }^{86} \mathrm{Sr}$ ratio of MORB, dolomite, magnesite, and calcite/aragonite are taken from [57]. The $\mathrm{Sr}, \mathrm{Cu}$, and $\mathrm{Zn}$ isotope ratios range of Kueishantao andesites are from [25] and this study. The $\mathrm{Cu}$ content (2.28 ppm) and $\mathrm{Cu}$ isotope composition $(+12.42 \%$ o ) of sedimentary carbonates were estimated from $[73,74]$. The $\mathrm{Cu}$ content and isotope composition of MORB are from $[5,75]$. Mixing hyperbolas are marked in $10 \%$ increments.

\section{Conclusions}

The Fe-Cu-Zn isotopic compositions $\left(\delta^{56} \mathrm{Fe}+0.22 \%\right.$, $\delta^{65} \mathrm{Cu}+0.16 \%$ o to $+0.64 \%$, and $\delta^{66} \mathrm{Zn}+0.29 \%$ to $+0.71 \%$ ) of the KHF andesites are significantly different from those of the previously studied MORB and CC and have a relatively wide range of $\mathrm{Cu}$ and $\mathrm{Zn}$ isotopic compositions, which are most easily explained as being a result of the entrainment of sedimentary carbonate-derived components, which are from the plate subduction and CC components, into andesitic magma. 
The majority of $\delta^{56} \mathrm{Fe}$ and $\delta^{57} \mathrm{Fe}$ values in the KHF andesites were higher than those in the sediments and the Taiwan local CC and lower than those in subducted altered rocks, while the reverse was true for $\delta^{66} \mathrm{Zn}$ and $\delta^{68} \mathrm{Zn}$, suggesting that subseafloor sediments and CC materials (lower $\delta^{56} \mathrm{Fe}$ and $\delta^{56} \mathrm{Fe}$, higher $\delta^{66} \mathrm{Zn}$ and $\delta^{68} \mathrm{Zn}$ ) inject rising andesitic magma and could preferentially incorporate isotopically heavy Fe and light $\mathrm{Zn}$ into the magma, resulting in the relative enrichment of the heavier Fe and lighter $\mathrm{Zn}$ isotopes in the andesites. As the KHF andesitic magmas have suffered extensively crustal contamination, complicating inferences about subduction-related metasomatism, a future study of the $\mathrm{Fe}-\mathrm{Cu}-\mathrm{Zn}$ isotopes of primitive basalt or mafic magmatic enclaves in this region will be helpful in distinguishing the different ways (crust contamination vs. source contamination) in which sedimentary carbonate-derived components are incorporated into the KHF andesitic magma.

Author Contributions: Writing—original draft, Z.Z. and X.L.; project administration, Z.Z.; writingreview and editing, Y.Z., Z.C. and C.-T.A.C.; investigation, S.C. All authors have read and agreed to the published version of the manuscript.

Funding: This work was supported by the NSFC Major Research Plan on West-Pacific Earth System Multispheric Interactions grant No. 91958213, the National Program on Global Change and Air-Sea Interaction grant No. GASI-GEOGE-02, the Taishan Scholar Foundation of Shandong Province grant No. ts201511061, and the National Key Basic Research Program of China grant No. 2013 CB429700.

Data Availability Statement: All the data that support the findings of this study are given in the main text.

Acknowledgments: We thank Bing-Jye Wang and the Sea-watch Company for the sampling of the andesite rocks in the KHF and Nadine Mattielli and Jeroen de Jong from Université Libre de Bruxelles for the $\mathrm{Fe}-\mathrm{Cu}-\mathrm{Zn}$ analyses of samples. We are most grateful for the detailed and constructive comments and suggestions provided by two anonymous reviewers, which greatly improved an earlier version of the manuscript.

Conflicts of Interest: The authors declare no conflict of interest.

\section{References}

1. Sharma, M.; Polizzotto, M.; Anbar, A.D. Iron isotopes in hot springs along the Juan de Fuca Ridge. Earth Planet. Sci. Lett. 2001, 194, 39-51. [CrossRef]

2. Rouxel, O.; Fouquet, Y.; Ludden, J.N. Subsurface processes at the lucky strike hydrothermal field, Mid-Atlantic ridge: Evidence from sulfur, selenium, and iron isotopes. Geochim. Cosmochim. Acta 2004, 68, 2295-2311. [CrossRef]

3. Mathur, R.; Titley, S.; Barra, F.; Brantley, S.; Wilson, M.; Phillips, A.; Munizaga, F.; Maksaev, V.; Vervoort, J.; Hart, G. Exploration potential of $\mathrm{Cu}$ isotope fractionation in porphyry copper deposits. J. Geochem. Explor. 2009, 102, 1-6. [CrossRef]

4. Li, W.Q.; Jackson, S.E.; Pearson, N.J.; Graham, S. Copper isotopic zonation in the Northparkes porphyry Cu-Au deposit, SE Australia. Geochim. Cosmochim. Acta 2010, 74, 4078-4096. [CrossRef]

5. Liu, S.-A.; Huang, J.; Liu, J.; Wörner, G.; Yang, W.; Tang, Y.-J.; Chen, Y.; Tang, L.-M.; Zheng, J.-P.; Li, S.-G. Copper isotopic composition of the silicate Earth. Earth Planet. Sci. Lett. 2015, 427, 95-103. [CrossRef]

6. John, S.G.; Rouxel, O.J.; Craddock, P.R.; Engwall, A.M.; Boyle, E.A. Zinc stable isotopes in seafloor hydrothermal vent fluids and chimneys. Earth Planet. Sci. Lett. 2008, 269, 17-28. [CrossRef]

7. Zeng, Z.G.; Li, X.H.; Chen, S.; de Jong, J.; Mattielli, N.; Qi, H.Y.; Pearce, C.; Murton, J.B. Iron, copper, and zinc isotopic fractionation in seafloor basalts and hydrothermal sulfides. Mar. Geol. 2021, 436, 106491. [CrossRef]

8. Yang, W.; Li, S.G. Geochronology and geochemistry of the Mesozoic volcanic rocks in Western Liaoning: Implications for lithospheric thinning of the North China Craton. Lithos 2008, 102, 88-117. [CrossRef]

9. Churikova, T.; Dorendorf, F.; Worner, G. Sources and fluids in the mantle wedge below Kamchatka, evidence from across-arc geochemical variation. J. Petrol. 2001, 42, 1567-1593. [CrossRef]

10. Münker, C.; Wörner, G.; Yogodzinski, G.; Churikova, T. Behaviour of high field strength elements in subduction zones: Constraints from Kamchatka-Aleutian arc lavas. Earth Planet. Sci. Lett. 2004, 224, 275-293. [CrossRef]

11. Abratis, M.; Wörner, G. Ridge collision, slab-window formation, and the flux of Pacific asthenosphere into the Caribbean realm. Geology 2001, 29, 127-130. [CrossRef]

12. Yogodzinski, G.; Lees, J.; Churikova, T.; Dorendorf, F.; Woerner, G.; Volynets, O. Geochemical evidence for the melting of subducting oceanic lithosphere at plate edges. Nature 2001, 409, 500-504. [CrossRef]

13. Savage, P.; Chen, H.; Shofner, G.; Badro, J.; Moynier, F. The copper isotope composition of bulk Earth: A new paradox. Goldschmidt Conf. Abstr. 2013, P2142. 
14. Toutain, J.P.; Sonke, J.; Munoz, M.; Nonell, A.; Polvé, M.; Viers, J.; Freydier, R.; Sortino, F.; Joron, J.L.; Sumarti, S. Evidence for Zn isotopic fractionation at Merapi volcano. Chem. Geol. 2008, 253, 74-82. [CrossRef]

15. Maréchal, C.N.; Télouk, P.; Albarède, F. Precise analysis of copper and zinc isotopic compositions by plasma-source mass spectrometry. Chem. Geol. 1999, 156, 251-273. [CrossRef]

16. Archer, C.; Vance, D. Mass discrimination correction in multiple-collector plasma source mass spectrometry: An example using $\mathrm{Cu}$ and $\mathrm{Zn}$ isotopes. J. Anal. At. Spectrom. 2004, 19, 656-665. [CrossRef]

17. Chen, C.A.; Zeng, Z.G.; Kuo, F.W.; Yang, T.F.; Wang, B.J.; Tu, Y.Y. Tide-influenced acidic hydrothermal system offshore NE Taiwan Chem. Geol. 2005, 224, 69-81. [CrossRef]

18. Chen, C.A.; Wang, B.J.; Huang, J.F.; Lou, J.Y.; Kuo, F.W.; Tu, Y.Y.; Tsai, H.S. Investigation into extremely acidic hydrothermal fluids off Kueishantao islet, Taiwan. Acta Oceanol. Sin. 2005, 24, 125-133.

19. Zeng, Z.G.; Liu, C.H.; Chen, C.-T.A.; Yin, Y.B.; Chen, D.G.; Wang, X.Y.; Wang, X.M.; Zhang, G.L. Origin of a native sulfur chimney in the Kueishantao hydrothermal field, offshore northeast Taiwan. Sci. China Ser. D 2007, 50, 1746-1753. [CrossRef]

20. Zeng, Z.G.; Chen, C.-T.A.; Yin, X.B.; Zhang, X.Y.; Wang, X.Y.; Zhang, G.L.; Wang, X.M.; Chen, D.G. Origin of native sulfur ball from the Kueishantao hydrothermal field offshore northeast Taiwan: Evidence from trace and rare earth element composition. $J$. Asian Earth Sci. 2011, 40, 661-671. [CrossRef]

21. Zeng, Z.G.; Wang, X.Y.; Chen, C.-T.A.; Yin, X.B.; Chen, S.; Ma, Y.Q.; Xiao, Y.K. Boron isotope compositions of fluids and plumes from the Kueishantao hydrothermal field off northeastern Taiwan: Implications for fluid origin and hydrothermal processes. Mar. Chem. 2013, 157, 59-66. [CrossRef]

22. Zeng, Z.G.; Ma, Y.; Wang, X.Y.; Chen, C.-T.A.; Yin, X.B.; Zhang, S.P.; Zhang, J.L.; Jiang, W. Elemental compositions of crab and snail shells from the Kueishantao hydrothermal field in the southwestern Okinawa Trough. J. Mar. Syst. 2018, 180, 90-101. [CrossRef]

23. Letouzey, J.; Kimura, M. Okinawa Trough genesis: Structure and evolution of a back arc basin developed in a continent. Mar. Pet. Geol. 1985, 2, 111-130. [CrossRef]

24. Chung, S.L.; Wang, S.L.; Shinjo, R.; Lee, C.S.; Chen, C.H. Initiation of arc magmatism in an embryonic continental rifting zone of the southernmost part of Okinawa Trough. Terra Nova 2000, 12, 225-230. [CrossRef]

25. Chen, C.-H.; Typhoon, L.; Shieh, Y.-N.; Chen, C.-H.; Hsu, W.-Y. Magmatism at the onset of back-arc basin spreading in the Okinawa Trough. J. Volcanol. Geotherm. Res. 1995, 69, 313-322.

26. Chen, Y.G.; Wu, W.S.; Chen, C.H.; Liu, T.K. A date for volcanic-eruption inferred from a siltstone xenolith. Quat. Sci. Rev. 2001, 20, 869-873. [CrossRef]

27. Petit, J.C.J.; de Jong, J.; Chou, L.; Mattielli, N. Development of Cu and Zn isotope MC-ICP-MS measurements: Application to suspended particulate matter and sediments from the Scheldt Estuary. Geostand. Geoanal. Res. 2008, 32, 149-166. [CrossRef]

28. Sossi, P.A.; Halverson, G.P.; Nebel, O.; Eggins, S.M. Combined separation of Cu, Fe and Zn from rock matrices and improved analytical protocols for stable isotope determination. Geostand. Geoanal. Res. 2015, 39, 129-149. [CrossRef]

29. Debret, B.; Beunon, H.; Mattielli, N.; Andreani, M.; da Coata, I.R.; Escartin, J. Ore component mobility, transport and mineralization at mid-oceanic ridges: A stable isotopes ( $\mathrm{Zn}, \mathrm{Cu}$ and $\mathrm{Fe}$ ) study of the Rainbow massif (Mid-Atlantic Ridge $36^{\circ} 14^{\prime} \mathrm{N}$ ). Earth Planet. Sci. Lett. 2018, 503, 170-180. [CrossRef]

30. Ponzevera, E.; Quétel, C.R.; Berglund, M.; Taylor, P.D.P. Mass Discrimination During MC-ICPMS Isotopic Ratio Measurements: Investigation by Means of Synthetic Isotopic Mixtures (IRMM-007 Series) and Application to the Calibration of Natural-Like Zinc Materials (Including IRMM-3702 and IRMM-651). J. Am. Soc. Mass Spectrom. 2006, 17, 1413-1427. [CrossRef]

31. Moeller, K.; Schoenberg, R.; Pedersen, R.-B.; Weiss, D.; Dong, S. Calibration of the new certified reference materials ERM-AE633 and ERM-AE647 for copper and IRMM-3702 for zinc isotope amount ratio determinations. Geostand. Geoanal. Res. 2012, 36, 177-199. [CrossRef]

32. Taylor, P.D.P.; Maeck, R.; De Bievre, P. Determination of the absolute isotopic composition and atomic weight of a reference sample of natural iron. Int. J. Mass Spectrom. Ion Processes 1992, 121, 111-125. [CrossRef]

33. Teng, F.-Z.; Dauphas, N.; Huang, S.; Marty, B. Iron isotopic systematics of oceanic basalts. Geochim. Cosmochim. Acta 2013, 107, 12-26. [CrossRef]

34. Beard, B.L.; Johnson, C.M.; Skulan, J.L.; Nealson, K.H.; Cox, L.; Sun, H. Application of Fe isotopes to tracing the geochemical and biological cycling of Fe. Chem. Geol. 2003, 195, 87-117. [CrossRef]

35. Rouxel, O.J.; Maureen, A. Iron Isotope Variations in Coastal Seawater Determined by Multicollector ICP-MS. Geostand. Geoanal. Res. 2010, 34, 135-144. [CrossRef]

36. Rouxel, O.; Dobbek, N.; Ludden, J.; Fouquet, Y. Iron isotope fractionation during oceanic crust alteration. Chem. Geol. 2003, 202, 155-182. [CrossRef]

37. Severmann, S.; Johnson, C.M.; Beard, B.L.; German, C.R.; Edmonds, H.N.; Chiba, H.; Green, D.R.H. The effect of plume processes on the Fe isotope composition of hydrothermally derived Fe in the deep ocean as inferred from the Rainbow vent site, Mid-Atlantic Ridge, $36^{\circ} 14^{\prime}$ N. Earth Planet. Sci. Lett. 2004, 225, 63-76. [CrossRef]

38. Rouxel, O.; Shanks, W.C., III; Bach, W.; Edwards, K.J. Integrated Fe- and S-isotope study of seafloor hydrothermal vents at East Pacific Rise $9-10^{\circ}$ N. Chem. Geol. 2008, 252, 214-227. [CrossRef]

39. Moeller, K.; Schoenberg, R.; Grenne, T.; Thorseth, I.H.; Drost, K.; Pedersen, R.B. Comparison of iron isotope variations in modern and Ordovician siliceous Fe oxyhydroxide deposits. Geochim. Cosmochim. Acta 2014, 126, 422-440. [CrossRef] 
40. Savage, P.; Moynier, F.; Cheng, H.; Shofner, G.; Siebert, J.; Badro, J.; Puchtel, I.S. Copper isotope evidence for large-scale sulphide fractionation during Earth's differentiation. Geochem. Perspect. Lett. 2015, 1, 53-64. [CrossRef]

41. Vance, D.; Archer, C.; Bermin, J.; Perkins, J.; Statham, P.J.; Lohan, M.C.; Ellwood, M.J.; Mills, R.A. The copper isotope geochemistry of rivers and the oceans. Earth Planet. Sci. Lett. 2008, 274, 204-213. [CrossRef]

42. Little, S.H.; Vance, D.; Walker-Brown, C.; Landing, W.M. The oceanic mass balance of copper and zinc isotopes, investigated by analysis of their inputs, and outputs to ferromanganese oxide sediments. Geochim. Cosmochim. Acta 2014, 125, 673-693. [CrossRef]

43. Dekov, V.; Rouxel, O. Cu- and Zn-isotope systematics of seafloor hydrothermal vent fluids from a back-arc setting (Manus Basin). In Proceedings of the EGU General Assembly, Vienna, Austria, 22-27 April 2012; p. 13020.

44. Ben Othman, D.; Luck, J.M.; Bodinier, J.L.; Arndt, N.T.; Albarède, F. Cu-Zn isotopic variations in the Earth's mantle. Geochim. Cosmochim. Acta 2006, 70, A46. [CrossRef]

45. Chen, H.; Savage, P.S.; Teng, F.-Z.; Helz, R.T.; Moynier, F. Zinc isotope fractionation during magmatic differentiation and the isotopic composition of the bulk Earth. Earth Planet. Sci. Lett. 2013, 369, 34-42. [CrossRef]

46. Wang, Z.-Z.; Liu, S.-A.; Liu, J.; Huang, J.; Xiao, Y.; Chu, Z.-Y.; Zhao, X.-M.; Tang, L. Zinc isotope fractionation during mantle melting and constraints on the Zn isotope composition of Earth's upper mantle. Geochim. Cosmochim. Acta 2017, 198, 151-167. [CrossRef]

47. Zhao, Y.; Vance, D.; Abouchami, W.; de Baar, H.J.W. Biogeochemical cycling of zinc and its isotopes in the Southern Ocean. Geochim. Cosmochim. Acta 2014, 125, 653-672. [CrossRef]

48. Samanta, M.; Ellwood, M.J.; Sinoir, M.; Hassler, C.S. Dissolved zinc isotope cycling in the Tasman Sea, SW Pacific Ocean. Mar. Chem. 2017, 192, 1-12. [CrossRef]

49. Pichat, S.; Douchet, C.; Albarède, F. Zinc isotope variations in deep-sea carbonates from the eastern equatorial Pacific over the last 175 ka. Earth Planet. Sci. Lett. 2003, 210, 167-178. [CrossRef]

50. Polyakov, V.B.; Mineev, S.D. The use of Mössbauer spectroscopy in stable isotope geochemistry. Geochim. Cosmochim. Acta 2000, 64, 849-865. [CrossRef]

51. Bullen, T.D.; White, A.F.; Childs, C.W.; Vivit, D.V.; Schulz, M.S. Demonstration of significant abiotic iron isotope fractionation in nature. Geology 2001, 29, 699-702. [CrossRef]

52. Schauble, E.A.; Rossman, G.R.; Taylor, H.P. Theoretical estimates of equilibrium Fe-isotope fractionations from vibrational spectroscopy. Geochim. Cosmochim. Acta 2001, 65, 2487-2497. [CrossRef]

53. Johnson, C.M.; Skulan, J.L.; Beard, B.L.; Sun, H.; Nealson, K.H.; Braterman, P.S. Isotopic fractionation between Fe(III) and Fe(II) in aqueous solutions. Earth Planet. Sci. Lett. 2002, 195, 141-153. [CrossRef]

54. Johnson, C.M.; Beard, B.L.; Beukes, N.J.; Klein, C.; O'Leary, J.M. Ancient geochemical cycling in the Earth as inferred from Fe isotope studies of banded iron formations from the Transvaal Craton. Contrib. Mineral. Petrol. 2003, 144, 523-547. [CrossRef]

55. Weyer, S.; Ionov, D.A. Partial melting and melt percolation in the mantle: The message from Fe isotopes. Earth Planet. Sci. Lett. 2007, 259, 119-133. [CrossRef]

56. Kunzmann, M.; Halverson, G.P.; Sossi, P.A.; Raub, T.D.; Payne, J.L.; Kirby, J. Zn isotope evidence for immediate resumption of primary productivity after snowball Earth. Geology 2013, 41, 27-30. [CrossRef]

57. Liu, S.-A.; Wang, Z.-Z.; Li, S.-G.; Huang, J.; Yang, W. Zinc isotope evidence for a large-scale carbonated mantle beneath eastern China. Earth Planet. Sci. Lett. 2016, 444, 169-178. [CrossRef]

58. Telus, M.; Dauphas, N.; Moynier, F.; Tissot, F.L.H.; Teng, F.Z.; Nabelek, P.I.; Craddock, P.R.; Groat, L.A. Iron, zinc, magnesium and uranium isotopic fractionation during continental crust differentiation: The tale from migmatites, granitoids, and pegmatites. Geochim. Cosmochim. Acta 2012, 97, 247-265. [CrossRef]

59. Sun, H.; Xiao, Y.; Gao, Y.; Lai, J.; Hou, Z.; Wang, Y. Fluid and melt inclusions in the Mesozoic Fangcheng basalt from North China Craton: Implications for magma evolution and fluid/melt-peridotite reaction. Contrib. Mineral. Petrol. 2013, 165, 885-901. [CrossRef]

60. Li, X.H.; Zeng, Z.G.; Chen, S.; Ma, Y.; Yang, H.X.; Zhang, Y.X.; Chen, Z.X. Geochemistry and Sr-Nd-Pb isotopic of volcanic rocks from Iheya Ridge, the middle Okinawa Trough: Implications for the petrogenesis and mantle source. Acta Oceanol. Sin. 2018, 37, 73-88. [CrossRef]

61. Li, X.H.; Zeng, Z.G.; Yang, H.X.; Yin, X.B.; Wang, X.Y.; Chen, S.; Ma, Y.; Guo, K. Geochemistry of silicate melt inclusions in middle and southern Okinawa Trough rocks: Implications for petrogenesis and variable subducted sediment component injection. Geol. J. 2018, 54, 1160-1189. [CrossRef]

62. Chen, C.-H.; Jahn, B.M.; Lee, T.; Chen, C.H.; Connichet, J. Sm-Nd isotopic geochemistry of sediments from Taiwan and complication for the tectonic evolution of SE China. Chem. Geol. 1990, 88, 317-332. [CrossRef]

63. Lan, C.Y.; Lee, T.; Wang Lee, C. The Rb-Sr isotopic record in Taiwan Gneisses and its tectonic implication. Tectonophysics 1990, 183, 129-143.

64. Sun, S.S.; McDonough, W.F. Chemical and isotopic systematics of oceanic basalts: Implications for mantle composition and processes. Geol. Soc. Lond. Spec. Publ. 1989, 42, 313-345. [CrossRef]

65. Rudnick, R.L.; Gao, S. Composition of the continental crust. In Treatise on Geochemistry; Holland, H.D., Turekian, K.K., Eds.; Elsevier Science Ltd.: Amsterdam, The Netherlands, 2003; Volume 3, pp. 1-64.

66. Vajk, R. Correction of gravity anomalies at sea for submarine topography. J. Geophys. Res. 1964, 69, 3837-3844. [CrossRef] 
67. Yeh, Y.H.; Lin, C.H.; Roecker, S.W. A study of upper crustal structures beneath northeastern Taiwan: Possible evidence of the western extension of Okinawa Trough. Proc. Geol. Soc. China 1989, 32, 139-156.

68. Lee, C.S.; Shor, G.G., Jr.; Bibee, L.D.; Lu, R.S.; Hilde, T.W.C. Okinawa Trough: Origin of a back-arc basin. Mar. Geol. 1980, 35, 219-241. [CrossRef]

69. Poitrasson, F.; Freydier, R. Heavy iron isotope composition of granites determined by high resolution MC-ICP-MS. Chem. Geol. 2005, 222, 132-147. [CrossRef]

70. Li, W.Q.; Jackson, S.E.; Pearson, N.J.; Alard, O.; Chappell, B.W. The Cu isotopic signature of granites from the Lachlan Fold Belt, SE Australia. Chem. Geol. 2009, 258, 38-49. [CrossRef]

71. Viers, J.; Oliva, P.; Nonell, A.; Gélabert, A.; Sonke, J.E.; Freydier, R.; Gainville, R.; Dupré, B. Evidence of Zn isotopic fractionation in a soil-plant system of a pristine tropical watershed (Nsimi, Cameroon). Chem. Geol. 2007, 239, 124-137. [CrossRef]

72. Shields, W.R.; Goldich, S.S.; Garner, E.L.; Murphy, T.J. Natural variations in the abundance ratio and the atomic weight of copper. J. Geophys. Res. 1965, 70, 479-491. [CrossRef]

73. Zhu, X.K.; O'Nions, R.K.; Guo, Y.; Belshaw, N.S.; Rickard, D. Determination of natural Cu-isotope variation by plasma-source mass spectrometry: Implications for use as geochemical tracers. Chem. Geol. 2000, 163, 139-149. [CrossRef]

74. Li, J.L.; Klemd, R.; Gao, J.; Meyer, M. Compositional zoning in dolomite from lawsonite-bearing eclogite (SW Tianshan, China): Evidence for prograde metamorphism during subduction of oceanic crust. Am. Mineral. 2014, 99, 206-217. [CrossRef]

75. Huang, J.; Liu, S.-A.; Gao, Y.; Xiao, Y.; Chen, S. Copper and zinc isotope systematics of altered oceanic crust at IODP Site 1256 in the eastern equatorial Pacific. J. Geophys. Res. Sol. Earth 2016, 121, 7086-7100. [CrossRef] 